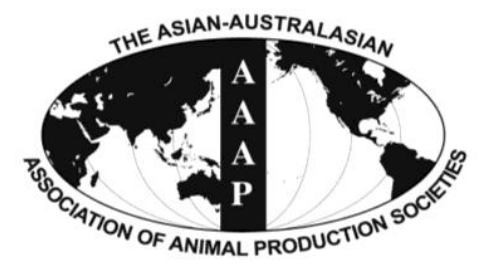

Asian-Aust. J. Anim. Sci.

Vol. 26, No. 3 : 423-432 March 2013

http://dx.doi.org/10.5713/ajas.2012.12417

www.ajas.info

pISSN 101 1-2367 elSSN 1976-5517

\title{
Selection of Reliable Reference Genes for Real-time qRT-PCR Analysis of Zi Geese (Anser anser domestica) Gene Expression
}

\author{
Hong $\mathrm{Ji}^{1,2, a}$, Jianfa Wang ${ }^{1,2, a}$, Juxiong Liu ${ }^{2}$, Jingru Guo ${ }^{1}$, Zhongwei Wang ${ }^{1}$, Xu Zhang ${ }^{1}$, \\ Li Guo ${ }^{1}$ and Huanmin Yang ${ }^{1, *}$ \\ ${ }^{1}$ College of Animal Science and Veterinary Medicine, Heilongjiang Bayi Agricultural University, Daqing 163319, China
}

\begin{abstract}
Zi geese (Anser anser domestica) belong to the white geese and are excellent layers with a superior feed-to-egg conversion ratio. Quantitative gene expression analysis, such as Real-time qRT-PCR, will provide a good understanding of ovarian function during egg-laying and consequently improve egg production. However, we still don't know what reference genes in geese, which show stable expression, should be used for such quantitative analysis. In order to reveal such reference genes, the stability of seven genes were tested in five tissues of $\mathrm{Zi}$ geese. Methodology/Principal Findings: The relative transcription levels of genes encoding hypoxanthine guanine phosphoribosyl transferase 1 (HPRT1), $\beta$-actin (ACTB), $\beta$-tubulin (TUB), glyceraldehyde-3-phosphatedehydrogenase (GADPH), succinate dehydrogenase flavoprotein (SDH), 28S rRNA (28S) and $18 S$ rRNA (18S) have been quantified in heart, liver, kidney, muscle and ovary in $\mathrm{Zi}$ geese respectively at different developmental stages (1 d, 2, 4, 6 and 8 months). The expression stability of these genes was analyzed using geNorm, NormFinder and BestKeeper software. Conclusions: The expression of $28 S$ in heart, GAPDH in liver and ovary, ACTB in kidney and HPRT1 in muscle are the most stable genes as identified by the three different analysis methods. Thus, these genes are recommended for use as candidate reference genes to compare mRNA transcription in various developmental stages of geese. (Key Words: Reference Genes, Real-time qRT-PCR, Zi Geese, Gene Expression)
\end{abstract}

\section{INTRODUCTION}

The research on improving egg production is always the focus on poultry breeding and management, especially for geese because of their poor laying performance and reproductive seasonality (Shi et al., 2008; Kang et al., 2009). $\mathrm{Zi}$ geese (Anser anser domestica) are excellent layers with a superior feed-to-egg conversion ratio. This species breeds only in northeast area of China including Heilongjiang and Jilin provinces. In domestic fowl breeding programs, the traditional method to improve egg production is to select those with the biggest egg-laying amount or the rate of lay (Kuhnlein et al., 1997). With the development of molecular biotechnologies such as genomics and proteomics analysis, alternative methods including selection of breeders with egg-laying or other important trait marker genes or proteins

\footnotetext{
* Corresponding Author: Huanmin Yang. Tel: +86-4596819190, Fax: +86-4596819190, E-mail: yanghuanmin@yahoo.com.cn

2 College of Animal Science and Veterinary Medicine, Heilongjiang Bayi Agricultural University, Daqing 163319, China.

${ }^{\mathrm{a}}$ These authors contributed equally.

Submitted Aug. 5, 2012; Accepted Sept. 10, 2012; Revised Oct. 31, 2012
}

are incorporated. Recent progress in molecular breeding technologies has provided tools to study complex biological traits under different physiological conditions using quantitative genes expression analysis (Chen et al., 2007). Among them, selection of breeders by comparing mRNA transcription between different domestic fowl samples has become a very important molecular biological protocol for improving egg production (Kuhnlein et al., 1997; Yen et al., 2006; Chen et al., 2007; Kang et al., 2009). In order to improve production performance of geese, researches on breeding and genetics should be focused on molecular genetic markers mapping, genome analysis and identification of candidate genes for specific performance.

Real-time quantitative reverse transcription polymerase chain reaction (Real-time qRT-PCR) is a major development of PCR technology that enables reliable detection and measurement of DNA (cDNA) generated during each cycle of PCR process (Arya et al., 2005). Realtime qRT-PCR, with its capacity to detect and measure very small amount of nucleic acids in a wide range of samples from numerous sources, has been used extensively in molecular biology, e.g., molecular diagnostics, life sciences, agriculture, and medicine. Real-Time qRT-PCR represents a 
rapid and reliable method for the detection and quantification of mRNA transcription levels of a selected gene in various biological specimens, or at different developmental stages or different physiological status (McCurley and Callard, 2008; Beekman et al., 2011). However, recently, a growing body of research have demonstrated that these genes expression can change in different tissues, during growth and differentiation, in response to biochemical stimuli, and in disease states (Janovick-Guretzky et al., 2007; Wen and Mao, 2007). The expression levels of the ideal endogenous reference genes should be constant in different experimental conditions. So the limitation for the application of qRT-PCR is the need for suitable internal reference genes which reduce the specimen differences and allow the quantification of this gene expression to be comparable (Huggett et al., 2005). It is well-known that normalization is critically important to reduce sample-to-sample variations, which includes the RT efficiency and RNA integrity, cDNA sample loading, instrumental errors, and the presence of PCR inhibitors etc. (Stahlberg et al., 2004; Bustin et al., 2005). Normalization of target gene expression levels must be performed before doing relative compaisions (Pfaffl et al., 2001). Several normalization strategies have been proposed, and the use of endogenous reference genes is currently the preferred one. An ideal endogenous reference gene used for normalization of data in quantitative real-time PCR should have the following features: constant expression levels among all individuals, organs and cells, during different developmental stages, and various experimental treatments (Jin et al., 2004). Usually, the well-known housekeeping genes are chosen such as the glyceraldehydes-3-phosphate dehydrogenase $(G A P D H), \beta$-actins $(A C T B)$, hypoxantine phosphoribosyltransferase (HRPT), $\beta$-tubulin (TUB), elongation factor 1 alpha (EF1A) and 18S, 28S rRNA (Shu et al., 2004; Fernandes et al., 2008; Øvergard et al., 2010). Several commonly used reference genes in studies of domestic fowl gene expression include the ACTB, GAPDH and $18 S$ rRNA. Shu et al. (2004) used $A C T B$ as a reference gene to study the expression level of three novel expressed sequence tags (ESTs) in hypothalamus, pituitary, muscle, liver and fat tissues of Shaoxing ducks (Shu et al., 2004). Scholz chose $18 S$ rRNA as the endogenous reference to analyze the sex-dependent gene expression level in early brain development of chicken embryos by Real-time PCR (Scholz1 et al., 2006). Yen used $A C T B$ as a reference gene for normalization of data in transcript analysis of pituitary gland genes in laying geese (Ding et al., 2007). Chen used $A C T B$ as a reference gene to analyze relative mRNA expression levels in the hypothalamus/pituitary glands in the Red-feather Taiwan country chicken which show significantly different reproductive performance (Chen et al., 2007). Ding chose $18 \mathrm{~S}$ rRNA as a reference gene for normalization of data in transcriptional analysis of Vitellogenin I, apoVLDL-II, ethanolamine kinase, Gprotein gamma-5 subunit, and leucyl-tRNA synthase expression level in the livers of the laying and pre-laying geese (Ding et al., 2007).

Thus far, the genes encoding GAPDH, ACTB and $18 S$ $r R N A$ have been used as endogenous reference genes for qRT-PCR in geese (Chen et al., 2007; Ding et al., 2007; Kang et al., 2009), but the stability analysis of these candidate genes in geese has not yet been reported. Based on earlier gene expression studies in domestic fowl, we have tested the stability of expression of seven housekeeping genes, including GAPDH, ACTB, HPRT1, $T U B$, succinate dehydrogenase flavoprotein A (SDHA), $18 S$ rRNA and 28S rRNA in this study. The geNorm (Vandesompe et al., 2002), Normfinder (Andersen et al., 2004), BestKeeper (Pfaffl et al., 2004), and the comparative $\Delta \mathrm{Ct}$ method are popular algorithms to determine the most stable endogenous reference genes from a set of tested candidate reference genes in a given experimental condition. Hence three different software tools were used to validate the stability of the selected housekeeping genes in different developmental stages ( $1 \mathrm{~d}, 2,4,6$ and 8 months old) of $\mathrm{Zi}$ geese tissues (heart, liver, kidney, muscle, ovary) using realtime qRT-PCR.

\section{MATERIALS AND METHODS}

\section{Geese and tissue collection}

The study protocol was approved by the Animal Care Committee of Jilin University. Thirty female $\mathrm{Zi}$ geese were randomly selected from one hundred geese in a local breeding farm and raised according to the standard program used at the farm (Daqing, China). Six geese were sacrificed at the age of $1 \mathrm{~d}, 2,4,6$ and 8 months respectively. Geese were sacrificed by electrical stunning followed by exsanguination. Heart, liver, kidney, muscle and ovary samples were rapidly removed, wrapped in foil, frozen in liquid nitrogen, and then stored at $-70^{\circ} \mathrm{C}$ until analysis.

\section{Total RNA isolation}

Total RNA was isolated from the $\mathrm{Zi}$ geese tissues (hearts, livers, kidneys, muscles and ovaries) at $1 \mathrm{~d}, 2,4,6$ and 8 months respectively according to the Trizol ${ }^{\circledR}$ reagent (Invitrogen, USA) manufacturer's instructions. Total RNAs were treated with DNase I (RNase Free, Takara, Japan) according to the manufacturer's instructions to remove contaminations of genomic DNA. Total RNA concentration and purity was determined using a SmartSpec ${ }^{\mathrm{TM}}$ Plus spectrophotometer (Bio-Rad, USA). The optical density (OD) ratio A260/A280 nm was measured with the spectrophotometer was $1.95 \pm 0.12$ (OD A260/A280 ratio \pm $\mathrm{SD})$. 
Table 1. Information of the seven candidate genes selected

\begin{tabular}{|c|c|c|c|c|c|c|c|c|}
\hline $\begin{array}{l}\text { Gene } \\
\text { name }\end{array}$ & $\begin{array}{c}\text { GenBank accession } \\
\text { number }\end{array}$ & $\begin{array}{l}\text { Primer sequences } \\
\text { (forward/reverse) }\end{array}$ & $\begin{array}{l}\mathrm{Tm} \\
\left({ }^{\circ} \mathrm{C}\right)\end{array}$ & $\begin{array}{l}\text { Amplicon } \\
\text { length (bp) }\end{array}$ & $\begin{array}{l}\text { Amplification } \\
\text { efficiency }(\%)\end{array}$ & $\begin{array}{l}\text { SD } \\
\text { (E) }\end{array}$ & $\mathrm{R}^{2}$ & $\begin{array}{l}\text { Average } \\
\text { Ct value }\end{array}$ \\
\hline GAPDH & AY436595.1 & $\begin{array}{l}\text { CTGTCAAGGCTGAGAATG } \\
\text { CAAGAGGCATTGCTGACA }\end{array}$ & 55 & 280 & 97.63 & 0.007 & 0.998 & 19.83 \\
\hline$H P R T 1$ & NM_204848.1 & $\begin{array}{l}\text { TGACTCTACCGACTATTGC } \\
\text { CATAGAGTCCGTCCAGTTT }\end{array}$ & 55 & 102 & 101.35 & 0.014 & 0.998 & $28 . .08$ \\
\hline$S D H$ & NM_001080875.1 & $\begin{array}{l}\text { ATCCATCGAGCCTTACC } \\
\text { CATAGAGTCCGTCCAGTTT }\end{array}$ & 55 & 101 & 91.28 & 0.010 & 0.998 & 28.14 \\
\hline$A C T B$ & M26111.1 & $\begin{array}{l}\text { CCATCTATGAGGGCTACGC } \\
\text { TTTAGCAGGCACTGTAGTTC }\end{array}$ & 55 & 149 & 93.43 & 0.010 & 0.996 & 36.91 \\
\hline$T U B$ & NM_001080860.2 & $\begin{array}{l}\text { GAGCGGAGCAGGAAACAAC } \\
\text { GCCAGTACCACCACCAAGA }\end{array}$ & 55 & 151 & 96.84 & 0.014 & 0.998 & 32.67 \\
\hline $28 S r R N A$ & EF552792.1 & $\begin{array}{l}\text { АТTCССАСТGТСССТАССТАС } \\
\text { СТСССАСТТАТССТАСАССТСТ }\end{array}$ & 55 & 144 & 98.03 & 0.016 & 0.994 & 33.53 \\
\hline $18 S$ rRNA & L21170.1 & $\begin{array}{l}\text { ACACGGACAGGATTGACA } \\
\text { ATCTCGGGTGGCTGAACG }\end{array}$ & 55 & 199 & 103.54 & 0.008 & 0.998 & 30.10 \\
\hline
\end{tabular}

For each reference gene, gene name, GenBank accession number, primer sequences, Tm value, amplicon length, amplification efficiencies (E) and its standard deviation (SD (E)), Pearson's coefficients of determination $\left(\mathrm{R}^{2}\right)$ and average cycle threshold values are indicated.

\section{Reverse transcription}

Total RNA $(1.5 \mu \mathrm{g})$ from $\mathrm{Zi}$ geese, $500 \mathrm{ng} / \mu \mathrm{l}$ of random hexamers primer (Promega, USA), $10 \mathrm{mM}$ deoxynucleoside triphosphate (dNTP) Mix (Takara) and sterile MilliQ water (to a total volume of $12 \mu \mathrm{l}$ ) were heated to $65^{\circ} \mathrm{C}$ for $5 \mathrm{~min}$ in order to disrupt possible secondary structures and then quickly chilled on ice. Thereafter, $5 \times$ First-Strand Buffer was combined with $0.1 \mathrm{M}$ dithiothreitol (DTT) and 40 units $\mu \mathrm{l}$ of $\mathrm{RNaseOUT}^{\mathrm{TM}}$ Recombinant Ribonu-clease Inhibitor (Invitrogen). The mixture was mixed gently and incubated at $37^{\circ} \mathrm{C}$ for $2 \mathrm{~min}$. Then a total of 200 units of MMLV reverse transcriptase was added and incubated at $25^{\circ} \mathrm{C}$ for $10 \mathrm{~min}$. Reverse transcription was performed at $37^{\circ} \mathrm{C}$ for $50 \mathrm{~min}$, and the reaction mixture was heated to $70^{\circ} \mathrm{C}$ for $15 \mathrm{~min}$. The final cDNA products were diluted 10 -fold prior to use in real-time PCR.

\section{Primer design}

All primers designed for all reference genes were based on sequences published in Genbank (http://www.ncbi.nlm. nih.gov/Table 1). Primer pairs for qPCR amplification were designed using Primer premier 5.0 (http://www. premierbiosoft.com), BLAST searches were performed to confirm the total gene specificity of the primer sequences (http://www.ncbi.nlm.nih.gov/BLAST/). The specificity of all primers was checked by electrophoresis of RT-PCR products on the $1 \%$ agarose gel (Figure 1a).

\section{Real-time qPCR}

The qRT-PCR was performed on the first strand cDNA using the Line-Gene K Real-time PCR Detection System and software (Bioer, China) with SYBR ${ }^{\circledR}$ Premix Ex Taq ${ }^{\mathrm{TM}}$ (Takara). Briefly, each reaction (50 $\mu \mathrm{l})$ consisted of $1 \mu \mathrm{l} 10$ - fold diluted cDNA template, $25 \mu \mathrm{l}$ of $\mathrm{SYBR}^{\circledR}$ Premix Ex $\mathrm{Taq}^{\mathrm{TM}}$ (2×Concentration), $0.5 \mu \mathrm{l}$ of $20 \mu \mathrm{M}$ of PCR Forward Primer and PCR Reverse Primer, and $23 \mu \mathrm{l}$ of nuclease-free water. Thermal cycling was performed with an initial denaturation step of $10 \mathrm{~s}$ at $94^{\circ} \mathrm{C}$, followed by 45 cycles of $5 \mathrm{~s}$ at $94^{\circ} \mathrm{C}$, and $56^{\circ} \mathrm{C}$ for $30 \mathrm{~s}$, and then a final extension at $72^{\circ} \mathrm{C}$ for $20 \mathrm{~s}$. Finally, a dissociation curve was generated by increasing temperature starting from 65 to $95^{\circ} \mathrm{C}$ to determine the specificity of the reactions. The crossing cycle number $(\mathrm{Cp})$ was automatically determined for each reaction by the Line-Gene K Real-Time PCR Detection System and software (Bioer) with default parameters using the second derivative method. As a control for genomic DNA contamination, an equivalent amount of total RNA without reverse transcription was tested for each reaction. A no-template control (NTC) was also included in each reaction. Relative quantitation of gene expression was performed in three replicates for each sample. The quality of standard curves was judged by the slope of the standard curve and the square of the Pearson correlation coefficient $\left(R^{2}\right)$. The PCR amplification efficiency of each primer pair is calculated from the slope of a standard curve using the following equation: Efficiency $\%=\left(10^{(-1 / \text { slope })}-1\right) \times 100 \%$ (Bustin et al., 2009).

\section{Statistical analysis}

Differences in expression levels of $G A P D H, A C T B$, HPRT1, TUB, SDHA, 18S rRNA and 28S rRNA with developmental stage were examined by one-way ANOVA. The IBM SPSS statistics 17.0 package (IBM, USA) was used for all analyses. Significance levels were set at $\mathrm{p}<0.05$. Determination of reference gene expression stability were calculated using geNorm, NormFinder and BestKeeper. 
(a)

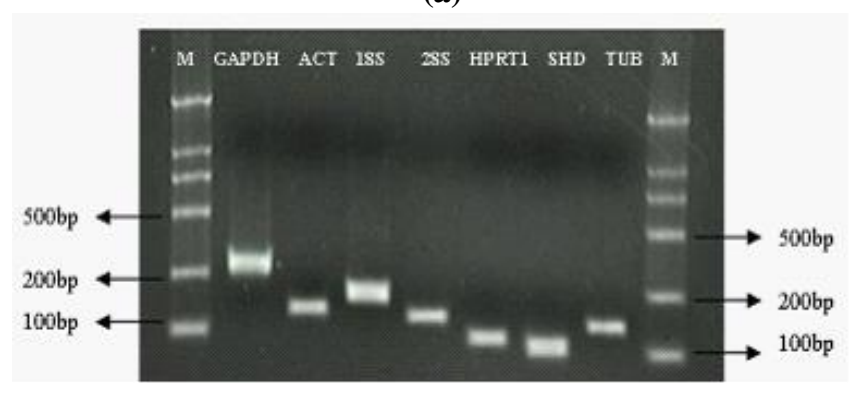

(b)

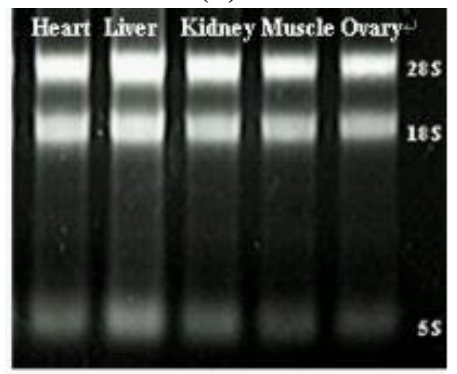

(c)

\section{GAPDH}
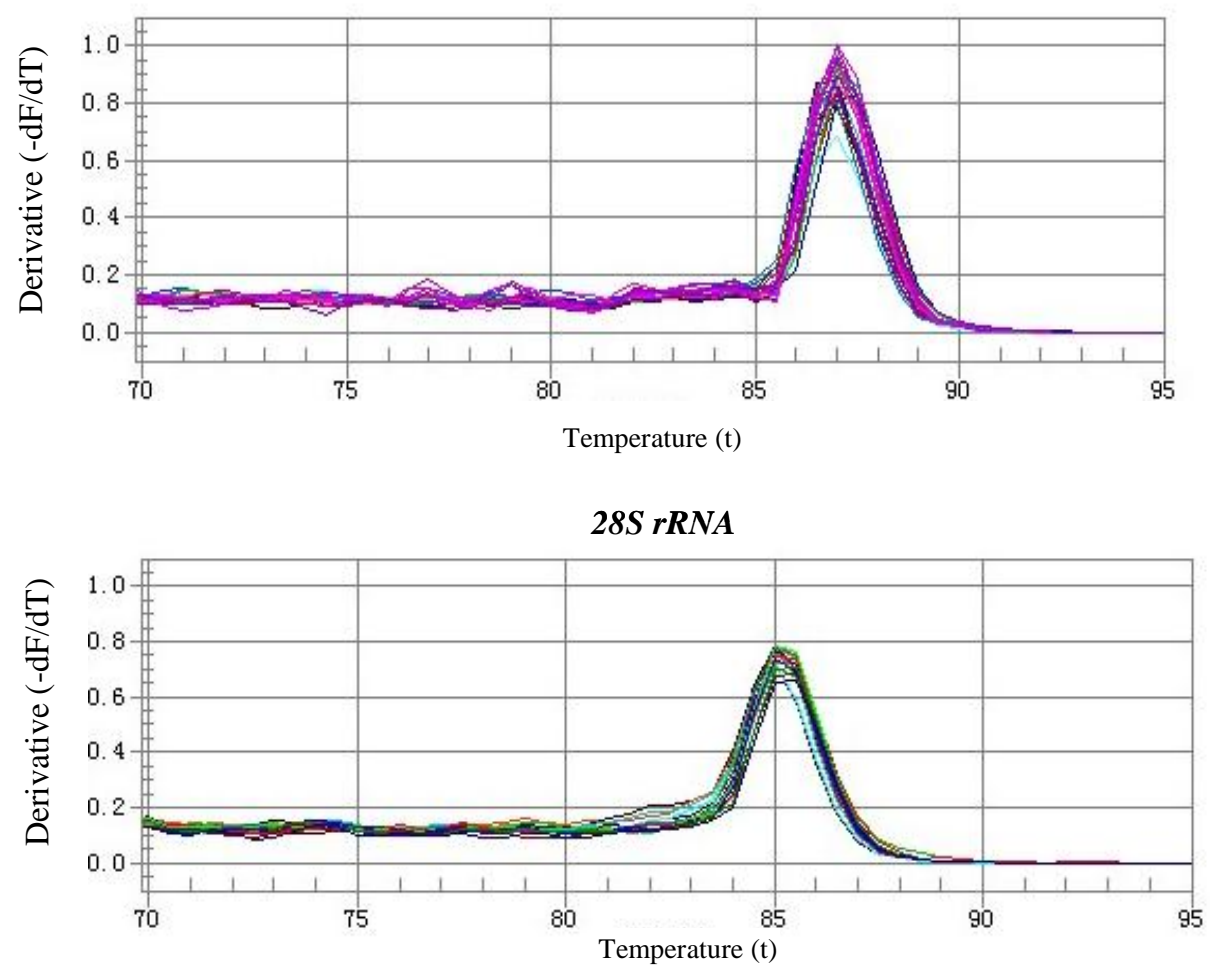

$S D H$

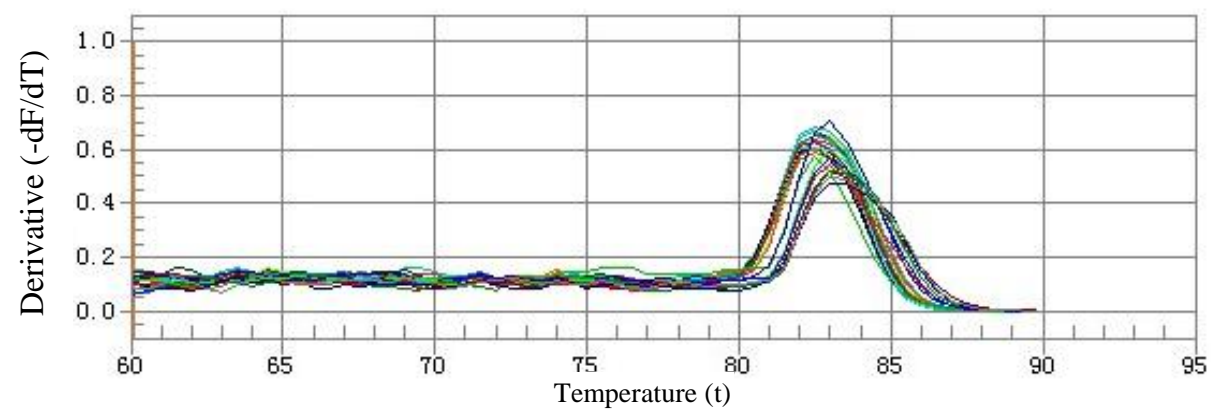

Figure 1. i) Confirmation of amplicon size and primer specificity of the selected genes. (a) Agarose gel electrophoresis showing the $28 \mathrm{~S}$ and $18 S$ rRNA bands. (b) Agarose gel electrophoresis showing specific RT-PCR products of the expected size for each gene. M represents DNA size marker. (c) Melting curves generated for all genes.

For evaluation of expression stability of the candidate reference genes, $\mathrm{Ct}$ values for all samples were calculated and the stability of the genes was determined utilizing three different software tools: geNorm, Normfinder and
BestKeeper. The gene expression stability (M) and the optimal number of endogenous reference genes for normalization were determined by using the geNorm algorithm as previously described (Vandesompe et al., 
(c) Continued

$A C T B$
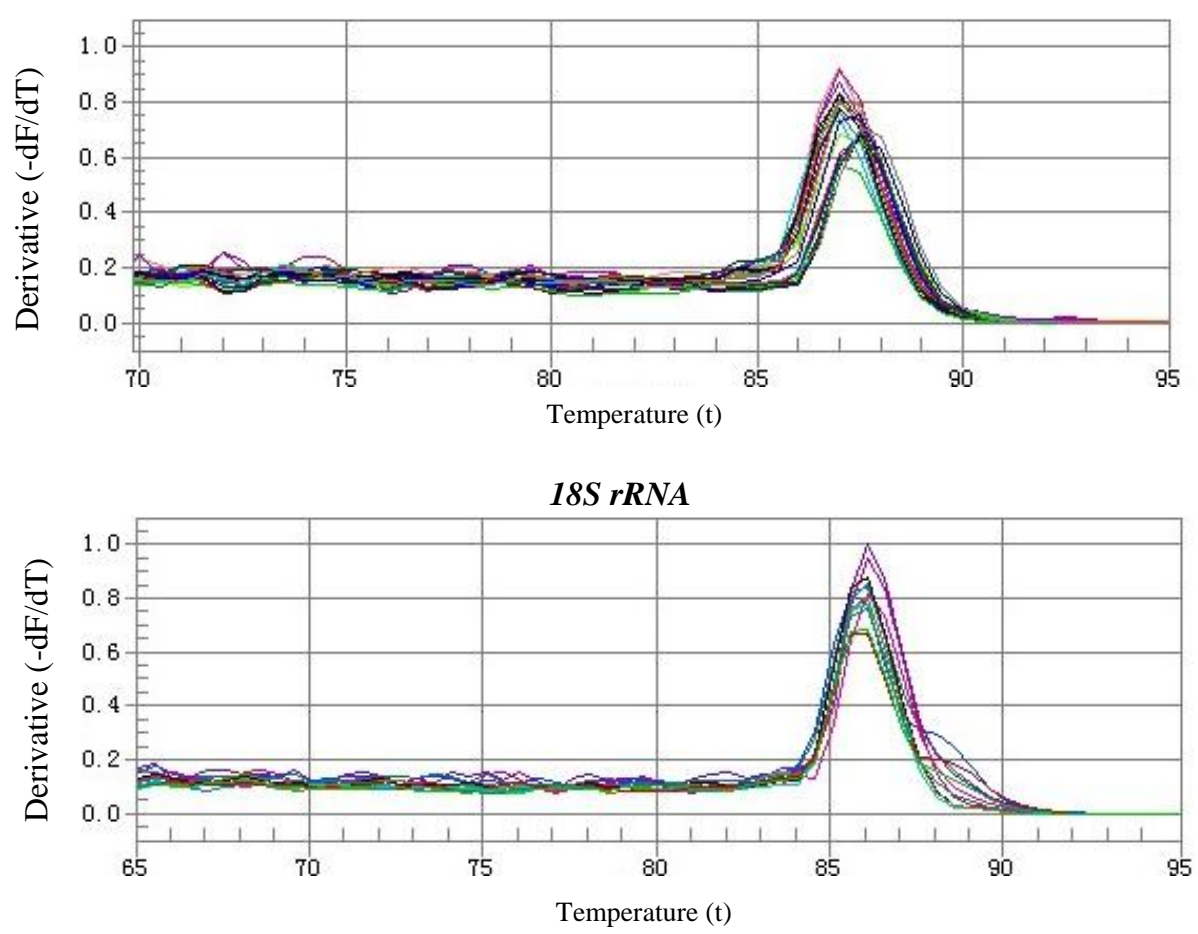

HPRT1

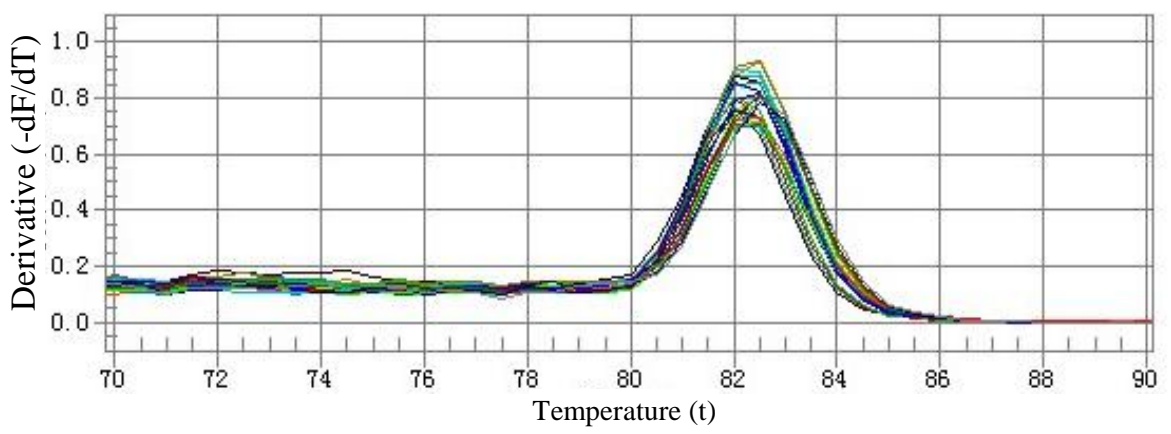

TUB

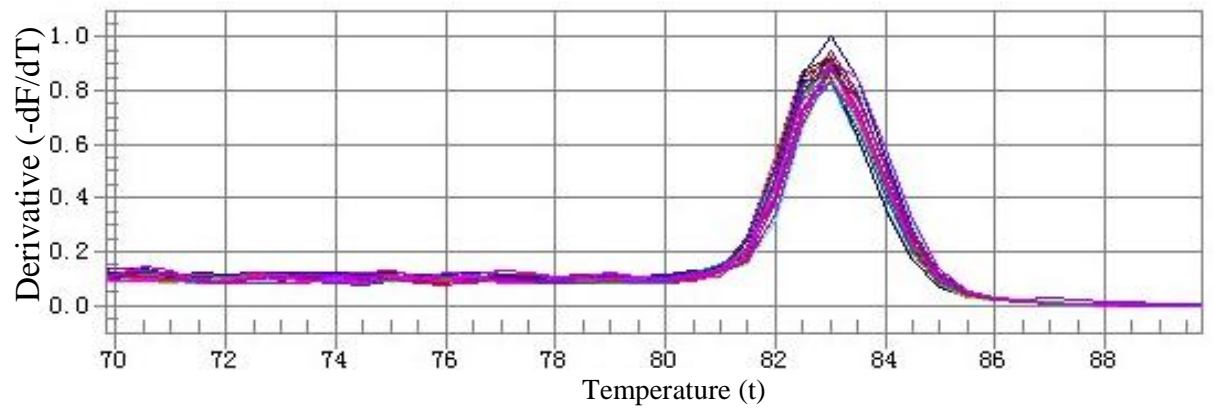

Figure 1. ii) Confirmation of amplicon size and primer specificity of the selected genes. (a) Agarose gel electrophoresis showing the $28 \mathrm{~S}$ and $18 S$ rRNA bands. (b) Agarose gel electrophoresis showing specific RT-PCR products of the expected size for each gene. M represents DNA size marker. (c) Melting curves generated for all genes.

2002). The second algorithm utilized was NormFinder as previously described by Andersen (Andersen et al., 2004). It is an algorithm that attempts to find the optimum reference genes out of a group of candidate genes. It can also, in contrast to geNorm, take information of groupings of samples into account, such as treatment/control, 
sick/healthy, or different developmental stages. The BestKeeper algorithm creates a pairwise correlation coefficient between each gene and the BestKeeper index (BI). This index was then compared to each individual candidate housekeeping gene by pair-wise correlation analyses, with each combination assigned a value for the Pearson correlation coefficient ( $\mathrm{r}$ ) and the probability (p) (Pfaffl et al., 2004). The gene with the highest coefficient of correlation with the BI indicates the highest stability.

\section{RESULTS}

\section{Selection of candidate reference genes and primer design}

We have investigated seven housekeeping genes commonly used as internal controls in expression studies, including the GAPDH, ACTB, HPRT1, TUB, SDHA, $18 S$ rRNA and $28 S$ rRNA. The primers were designed according to the $\mathrm{Zi}$ geese mRNA sequences which are available in GenBank (Table 1).

\section{Quality control of the nucleic acids and qPCR}

The optical density (OD) ratio A260/A280 of the RNA was 1.8 to 2.0. Agarose gel electrophoresis (Figure 1b) that $28 \mathrm{~S}: 18 \mathrm{~S}$ ratio was approximately $2: 1$ indicated that the RNA was intact. Agarose gel electrophoresis (Figure 1a) and melting curve analysis (Figure 1c and Table 1) revealed that all primer pairs amplified a single PCR product with the expected size. Furthermore, sequence analysis of cloned amplicons revealed that all sequenced amplified fragments were identical or nearly identical to the sequences generated by the designed primers. In order to quantitatively determine the transcriptional level of each candidate gene, the average cycle threshold $(\mathrm{Ct})$ value of each gene was calculated (Table 1). As expected, the average $\mathrm{Ct}$ value of different gene varied. A standard curve using a dilution series of the cloned amplicons was made to calculate the gene-specific PCR efficiency. The correlation coefficient $\left(R^{2}\right)$ of the slope of the standard curve, the PCR amplification efficiency (E) and the PCR efficiency standard deviation (SD) of each gene were listed in Table 1. All primer pairs utilized in this study presented amplification efficiency between 91 to $104 \%$ (Table 1).

\section{Expression stability of candidate reference genes}

Three different software tools were used to calculate the expression stability of the candidate reference genes: geNorm, NormFinder and BestKeeper.

\section{geNorm analysis}

In present study, average expression stability ( $\mathrm{M}$ value) of all genes was calculated by geNorm (version 3.5). The M values of the candidate reference genes across $\mathrm{Zi}$ geese tissues (heart, liver, kidney, muscle,oaries) are shown in Table 2. GAPDH and $28 S$ had the highest expression stability in $\mathrm{Zi}$ geese heart tissues, (the lowest $\mathrm{M}$ values). $G A P D H$ and $S D H$ had the highest expression stability in liver tissues, $A C T B$ and $S D H$ had the highest expression stability in kidney tissues, HPRT1 and $18 S$ had the highest expression stability in $\mathrm{Zi}$ geese muscle tissues, GAPDH and HPRT1 had the highest expression stability in ovaries tissues. TUB (heart, kidney and muscle), $18 S$ (ovarie) and $A C T B$ (liver) had the highest $\mathrm{M}$ values, indicating less stable expression across $\mathrm{Zi}$ geese tissues (Table 2). In different developmental stages of $\mathrm{Zi}$ geese heart tissue, low V4/5 value $=0.210$, the 4 member set $G A P D H, 28 S, S D H$ and $A C T B$ is an excellent choice for the calculation of the NF. In liver tissue, low V3/4 value $=0.237$, the 3 member set GAPDH, HPRTI and SDH is an excellent choice for the calculation of the NF. In kidney tissues, the inclusion of a 4th gene has no significant effect (low V3/4 value = $0.148<1.5$ ) on the NF. The 3 member set ATC, GAPDH and $\mathrm{SDH}$ is an excellent choice for the calculation of the NF. In muscle tissue, low V2/3 value $=0.124<1.5$, the 2 member set HPRT1 and $18 S$ is an excellent choice for the calculation of the NF. In oaries tissue, low V2/3 value $=0.152$, the 2 member set GAPDH and HPRTI is an excellent choice for the calculation of the NF.

\section{NormFinder analysis}

Table 2 shows the ranking order of the seven candidate reference genes mentioned above, using the NormFinder program to calculate their expression stability. Genes that are more stably expressed are indicated by lower average expression stability values. The analysis ranks $28 S, S D H$, GAPDH and HPRT1 were the four most stable genes in different developmental stages of $\mathrm{Zi}$ geese heart tissues (Table 2). SDH, GAPDH and HPRTI were the three most stable genes in liver tissues. $S D H, A C T B$ and $G A P D H$ were the three most stable genes in kidney tissues. $G A P D H$ and $28 S$ were the two most stable genes in muscle tissues. GAPDH and HPTRl were the two most stable genes in oaries tissues. Thus, both geNorm and NormFinder rank the same genes as the most stable and the entire order is identical.

\section{BestKeeper analysis}

The results of reference gene evaluation by the BestKeeper tool are shown in Table 2. The BestKeeper revealed that in different developmental stages of $\mathrm{Zi}$-geese heart tissues the best correlations were obtained for $S D H$ (r $=0.903)$, GAPDH $(\mathrm{r}=0.881), 28 S(\mathrm{r}=0.857)$ and HPRT1 $(\mathrm{r}=0.846)$ with $\mathrm{p}$ value of 0.001 (Table 2). TUB are ranked as the least stable genes. In liver tissues the best correlations were obtained for GAPDH $(\mathrm{r}=0.951), 28 S(\mathrm{r}=0.916)$ and $18 S(\mathrm{r}=0.909)$ with $\mathrm{p}$ value of $0.001 . T U B$ are ranked as 
Table 2. Ranking of the candidate reference genes to be used in different tissues of $\mathrm{Zi}$ geese

\begin{tabular}{|c|c|c|c|c|c|c|}
\hline \multirow{2}{*}{ Gene name } & \multicolumn{3}{|c|}{ Stability value } & \multicolumn{3}{|c|}{ Ranking order } \\
\hline & geNorm & NormFinder & BestKeeper & geNorm & NormFinder & BestKeeper \\
\hline \multicolumn{7}{|l|}{ Heart } \\
\hline$G A P D H$ & 0.62 & 0.580 & 0.881 & 1 & 3 & 2 \\
\hline $28 S$ rRNA & 0.62 & 0.144 & 0.857 & 1 & 1 & 3 \\
\hline$S D H$ & 0.78 & 0.222 & 0.903 & 2 & 2 & 1 \\
\hline$A C T B$ & 0.97 & 0.867 & 0.843 & 3 & 6 & 5 \\
\hline $18 S$ rRNA & 1.06 & 0.749 & 0.828 & 4 & 5 & 6 \\
\hline HPRT1 & 1.15 & 0.691 & 0.846 & 5 & 4 & 4 \\
\hline$T U B$ & 1.48 & 1.497 & 0.715 & 6 & 7 & 7 \\
\hline \multicolumn{7}{|l|}{ Liver } \\
\hline GAPDH & 0.38 & 0.134 & 0.951 & 1 & 2 & 1 \\
\hline$H P R T 1$ & 0.38 & 0.264 & 0.423 & 1 & 3 & 6 \\
\hline$S D H$ & 0.62 & 0.072 & 0.311 & 2 & 1 & 7 \\
\hline$T U B$ & 0.81 & 0.674 & 0.884 & 3 & 4 & 4 \\
\hline $28 S r R N A$ & 0.99 & 0.684 & 0.916 & 4 & 5 & 2 \\
\hline $18 S r R N A$ & 1.19 & 1.193 & 0.909 & 5 & 6 & 3 \\
\hline$A C T B$ & 1.50 & 1.496 & 0.513 & 6 & 7 & 5 \\
\hline \multicolumn{7}{|l|}{ Kideny } \\
\hline$A C T B$ & 0.25 & 0.107 & 0.975 & 1 & 2 & 1 \\
\hline$S D H$ & 0.25 & 0.086 & 0.943 & 1 & 1 & 2 \\
\hline$G A P D H$ & 0.52 & 0.297 & 0.936 & 2 & 3 & 3 \\
\hline HPRT 1 & 0.59 & 0.449 & 0.900 & 3 & 4 & 4 \\
\hline $28 S r R N A$ & 0.68 & 0.657 & 0.897 & 4 & 6 & 5 \\
\hline $18 S$ rRNA & 0.81 & 0.594 & 0.594 & 5 & 5 & 7 \\
\hline$T U B$ & 0.91 & 0.725 & 0.880 & 6 & 7 & 6 \\
\hline \multicolumn{7}{|l|}{ Muscle } \\
\hline HPRT1 & 0.40 & 0.299 & 0.980 & 1 & 3 & 1 \\
\hline $18 S$ rRNA & 0.40 & 0.474 & 0.979 & 1 & 5 & 2 \\
\hline$G A P D H$ & 0.42 & 0.034 & 0.901 & 2 & 1 & 5 \\
\hline $28 S$ rRNA & 0.46 & 0.125 & 0.974 & 3 & 2 & 3 \\
\hline$S D H$ & 0.54 & 0.473 & 0.971 & 4 & 4 & 4 \\
\hline$A C T B$ & 0.68 & 0.494 & 0.861 & 5 & 6 & 6 \\
\hline$T U B$ & 0.91 & 0.970 & 0.801 & 6 & 7 & 7 \\
\hline \multicolumn{7}{|l|}{ Ovary } \\
\hline$G A P D H$ & 0.26 & 0.090 & 0.914 & 1 & 1 & 1 \\
\hline$H P R T 1$ & 0.26 & 0.090 & 0.853 & 1 & 1 & 3 \\
\hline$S D H$ & 0.40 & 0.162 & 0.876 & 2 & 2 & 2 \\
\hline$T U B$ & 0.60 & 3.890 & 0.740 & 3 & 6 & 4 \\
\hline $18 S r R N A$ & 0.74 & 0.431 & 0.604 & 4 & 3 & 5 \\
\hline$A C T B$ & 1.11 & 1.216 & 0.564 & 5 & 4 & 6 \\
\hline $28 S r R N A$ & 1.35 & 1.649 & -2.16 & 6 & 5 & 7 \\
\hline
\end{tabular}

the least stable genes. In kidney tissues the best correlations were obtained for $A C T B(\mathrm{r}=0.975), S D H(\mathrm{r}=0.943)$ and GAPDH $(\mathrm{r}=0.936)$ with $\mathrm{p}$ value of $0.001 . T U B$ are ranked as the least stable genes. In muscle tissues the best correlations were obtained for HPRTI $(\mathrm{r}=0.980)$ and $18 \mathrm{~S}$ $(\mathrm{r}=0.979)$ with $\mathrm{p}$ value of 0.001 . TUB are ranked as the least stable genes. In ovaries tissues the best correlations were obtained for $G A P D H(\mathrm{r}=0.914)$ and $S D H(\mathrm{r}=0.876)$ with $\mathrm{p}$ value of 0.001 . $28 \mathrm{~S}$ are ranked as the least stable genes.

\section{DISCUSSION}

Real-time qRT-PCR, with its capacity to detect and 
measure very small amount of nucleic acids in a wide range of samples from numerous sources, has been used extensively in molecular biology, e.g., molecular diagnostics, life sciences, agriculture, and medicine. Normalization is required to reduce the tube-to-tube variations caused by variable RNA quality or reverse transcription efficiency, inaccurate quantification, and pipetting etc (O'Connell, 2002). Endogenous reference genes are thus commonly used to normalize the expression levels of analyzed genes. $A C T B$, together with $G A P D H$, $T U B, E F 1 A$ and $18 S$ rRNA, are expressed constitutively and are involved in basic housekeeping functions required for cell maintenance. Because of this, they are commonly used as reference genes to normalize gene expression studies (Sturzenbaum and Kille, 2001; Jin et al., 2004; Wen and Mao, 2007; Øvergard et al., 2010). Recently, a growing body of research has demonstrated that these genes expression can change in different tissues, during growth and differentiation, in response to biochemical stimuli, and in disease states (Wen and Mao, 2007; Janovick-Guretzky et al., 2007). The expression levels of the ideal endogenous reference genes should be constant in different experimental conditions. The geNorm, Normfinder, BestKeeper, and the comparative $\Delta \mathrm{Ct}$ method are popular algorithms to determine the most stable endogenous reference genes from a set of tested candidate reference genes in a given experimental condition.

In this study, we have selected seven candidate reference genes from Genbank to analyze their candidacy to be used as reference genes. Also, we have developed a qRTPCR method for GAPDH, HPRT1, ACTB, 18S, 28S, SDHA and $T U B$ as the target gene. The specificity of the qRT-PCR primer pairs was confirmed by agarose gel electrophoresis, Tm analysis and sequencing of the amplicons. The PCR amplification efficiency was estimated, and the reference genes were ranked according to their expression level stability across various developmental stages in $\mathrm{Zi}$ geese tissues using geNorm, Normfinder and BestKeeper algorithms. When gene expression stability in $\mathrm{Zi}$ geese was analyzed by geNorm, which had been recently noted as one of the best methods to determine the most stably expressed genes for qRT-PCR analysis $(10,8)$, the most stable genes in the seven series were different as shown in Table 2 and Figure 2. In different developmental stages of $\mathrm{Zi}$ geese heart tissues, the stability rank was $G A P D H, 28 S>S D H>A C T B$ $>18 S>H P R T 1>T U B$, and the optimal number of reference genes was four. In order to avoid co-regulation, we have also determined the stability of the selected genes using Normfinder and BestKeeper. The 28S, SDH, GAPDH and HPRT1, as identified by both the NormFinder and the BestKeeper tools, were the four most stable genes, which supported the geNorm analysis in this experiment. The stability of the four genes, from the highest to the lowest, was $28 S, S D H, G A P D H$ and HPRT1. In liver tissues, the stability ranking was $G A P D H, H P R T 1>S D H>T U B>28 S$ $>18 S>A C T B$, and optimal number of reference genes was three. In kidney tissues, the stability ranking was $A C T B$, $S D H>G A P D H>H P R T 1>28 S>18 S>T U B$, and the optimal number of reference genes was three. In conclusion, the three algorithms did not rank the candidate reference genes in the same order, but all indicated that $A C T B, S D H$ and $G A P D H$ should be the most stably expressed genes in the experimental conditions applied in this study. In muscle, the stability ranking was $H P R T 1,18 S>G A P D H>28 S>S D H$ $>A C T B>T U B$, and the optimal number of reference genes was two. In ovary, the stability ranking was $G A P D H$, $H P R T 1>S D H>T U B>18 S>A C T B>28 S$, and the optimal number of reference genes was two. The NormFinder identified that GAPDH and HPRTI to be the two most stable genes whereas, in contrast, the BestKeeper identified $G A P D H$ and $S D H$ to be the two most stable genes.

\section{IMPLICATIONS}

This research is the first attempt to validate a set of commonly used candidate reference genes in various

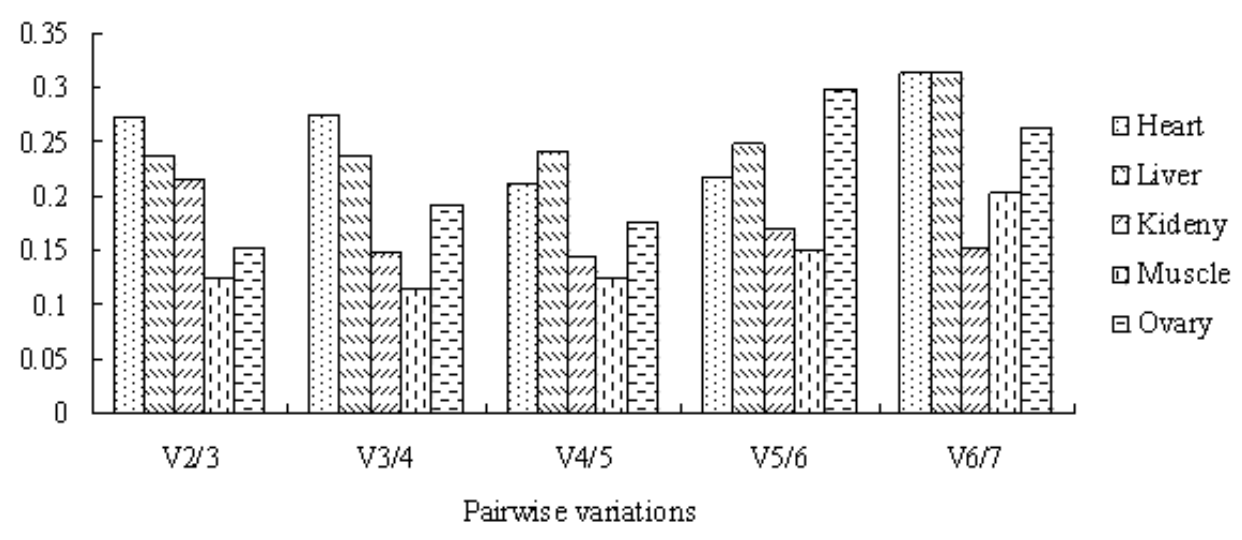

Figure 2. Determination of the optimal number of reference genes calculated by geNorm. The reference genes were ranked according to their expression levels stability across various developmental stages in $\mathrm{Zi}$ geese tissues using geNorm. When gene expression stability in $\mathrm{Zi}$ geese was analyzed by geNorm, the stability were different in heart, liver, kideny, muscle and ovary. 
developmental stages in $\mathrm{Zi}$ geese tissues for the normalization of gene expression using qRT-PCR. Analysis of stability using geNorm, NormFinder and BestKeeper reveals that the geometric mean of $G A P D H, 28 S, S D H$ and HPRT1 (in heart), GAPDH, HPRT1 and $S D H$ (in liver), $A C T B, S D H$ and GAPDH (in kidney), HPRT1 and $18 S$ (in muscle), and GAPDH and HPRT1 (in ovary) are recommended to be used as reference genes in $\mathrm{Zi}$ geese. These methods may further be employed to identify the most stable reference genes in other tissues or under other experimental conditions in the future studies on geese. Also, this study may serve as a good foundation for further studies on how to improve the economic traits of geese, both in egg, fatty livers and meat production.

\section{ACKNOWLEDGEMENTS}

The work was supported by the Natural Science Foundation of Heilongjiang Province of China (ZD201116). The authors would like to thank Mrs. Yibing Han, for her valuable time in providing language help. We also thank the anonymous reviewers for their valuable comments and suggestions.

\section{REFERENCES}

Andersen, C. L., J. L. Jensen and T. F. Ørntoft. 2004. Normalization of real-time quantitative reverse transcriptionPCR data: A model-based variance estimation approach to identify genes suited for normalization, applied to bladder and colon cancer data sets. Cancer Res. 64:5245-5250.

Arya, M., I. S. Shergill, M. Williamson, L. Gommersall, N. Arya and H. R. Patel. 2005. Basic principles of real-time quantitative PCR. Expert Rev. Mol. Diagn. 5:209-219.

Beekman, L., T. Tohver, R. Dardari and R. Léguillette. 2011. Evaluation of suitable reference genes for gene expression studies in bronchoalveolar lavage cells from horses with inflammatory airway disease. BMC. Mol. Biol. 12:5.

Bustin, S. A., V. Benes, T. Nolan and M. W. Pfaffl. 2005. Quantitative real-time RT-PCR-a perspective. J. Mol. Endocrinol. 34:597-601.

Bustin, S. A., V. Benes, J. A. Garson, J. Hellemans, J. Huggett, M. Kubista, R. Mueller, T. Nolan, M. W. Pfaffl, G. L. Shipley, J. Vandesompele and C. T. Wittwer. 2009. The MIQE guidelines: minimum information for publication of quantitative real-time PCR experiments. Clin. Chem. 55:4611-4622.

Chen, L. R., C. H. Chao, C. F. Chen, Y. P. Lee, Y. L. Chen and Y. L. Shiu. 2007. Expression of 25 high egg production related transcripts that identified from hypothalamus and pituitary gland in red-feather Taiwan country chickens. Anim. Reprod. Sci. 100:172-185.

Ding, S. T., C. F. Yen, P. H. Wang, H. W. Lin, J. C. Hsu and T. F. Shen. 2007. The differential expression of hepatic genes between prelaying and laying geese. Poult. Sci. 86:1206-1212.

Fernandes, J. M. O., M. Mommens, Ø. Hagen, I. Babiak and C. Solberg. 2008. Selection of suitable reference genes for real- time PCR studies of Atlantic halibut development. Comp. Biochem. Physiol. B Biochem. Mol. Biol. 150:23-32.

Huggett, J., K. Dheda, S. Bustin and A. Zumla. 2005. Real-time RT-PCR normalisation; strategies and considerations. Genes Immun. 6:279-284.

Janovick-Guretzky, N. A., H. M. Dann, D. B. Carlson, M. R. Murphy, J. J. Loor and J. K. Drackley. 2007. Housekeeping gene expression in bovine liver is affected by physiological state, feed intake, and dietary treatment. J. Dairy Sci. 90:22462252.

Jin, P., Y. D. Zhao, Y. Ngalame, M. C. Panelli, D. Nagorsen, V. Monsurro, K. Smith, V. Hu, H. Su, P. R. Taylor, F. M. Marincola and E. Wang. 2004. Selection and validation of endogenous reference genes using a high throughput approach. BMC. Genomics 5:55.

Kang, B., J. R. Guo, H. M. Yang, R. J. Zhou, J. X. Liu, S. Z. Li and C. Y. Dong. 2009. Differential expression profiling of ovarian genes in prelaying and laying geese. Poult. Sci. 88: 1975-1983.

Kuhnlein, U., L. Ni, D. Zadworny, S. Weigend, J. S. Gavora and W. Fairfull. 1997. DNA polymorphisms in the chicken growth hormone gene: response to selection for disease resistance and association with egg production. Anim. Genet. 28:116-123.

McCurley, A. T. and G. V. Callard. 2008. Characterization of housekeeping genes in zebrafish: male-female differences and effects of tissue type, developmental stage and chemical treatment. BMC. Mol. Biol. 9:102.

O'Connell, J. 2002. RT-PCR protocols. Meth. in Mol. Biol. Humana. Press Inc., Totowa, NJ, USA. 193, 84.

Øvergard, A. C., A. H. Nerland and S. Patel. 2010. Evaluation of potential reference genes for real time RT-PCR studies in Atlantic halibut (Hippoglossus Hippoglossus L.); during development, in tissues of healthy and NNV-injected fish, and in anterior kidney leucocytes. BMC. Mol. Biol. 11:36.

Pfaffl, M. W. and M. Hageleit. 2001. Validities of mRNA quantification using recombinant RNA and recombinant DNA external calibration curves in real-time RT-PCR. Biotechnol. Lett. 23:275-282.

Pfaffl, M. W., A. Tichopad, C. Prgomet and T. P. Neuvians. 2004. Determination of stable housekeeping genes, differentially regulated target genes and sample integrity: BestKeeper-Excel-based tool using pair-wise correlations. Biotechnol. Lett. 26:509-515.

Scholz1, B., K. Kultima1, A. Mattsson, J. Axelsson, B. Brunström, K. Halldin, M. Stigson and L. Dencker. 2006. Sex-dependent gene expression in early brain development of chicken embryos. BMC Neurosci. 7:12.

Shi, Z. D., T. B. Tian, W. Wu and Z. Y. Wang. 2008. Controlling reproductive seasonality in the geese: a review. World Poult. Sci. J. 64:343-355.

Shu, G., J. Chen, Y. D. Ni, Y. C. Zhou and R. Q. Zhao. 2004. Isolatin and expression of novel exp ressed sequence tags (ESTs) from ovarian follicles of shaoxing ducks. Acta Genet. Sin. 31:1095-1102.

Stahlberg, A., J. Hakansson, X. J. Xian, H. Semb and M. Kubista. 2004. Properties of the reverse transcription reaction in mRNA quantification. Clin. Chem. 50:509-515.

Sturzenbaum, S. R. and P. Kille. 2001. Control genes in quantitative molecular biological techniques: the variability of 
invariance. Comp. Biochem. Physiol. B Biochem. Mol. Biol. Wen, J. R. and D. L. Mao. 2007. Actin, a reliable marker of 130:281-289. internal control? Clin. Chim. Acta. 385:1-5.

Vandesompe, J., K. De Preter, F. Pattyn, B. Poppe, N. Van Roy, A. Yen, C. F., H. W. Lin, J. C. Hsu, C. Lin, T. F. Shen and S. T. Ding. De, Paepe and F. Speleman. 2002. Accurate normalization of real-time quantitative RT-PCR data by geometric averaging of multiple internal control genes. Genome Biol. 3:1-12. 2006. The expression of pituitary gland genes in laying geese. Poult. Sci. 85:2265-2269. 